\title{
COMMENTARY
}

\section{Care of caregivers - who is responsible?}

\section{Karpaga Priya $\mathbf{P}^{1}$, Gouri Kumari Padhy ${ }^{2}$, Mohan Kumar ${ }^{3}$}

${ }^{1}$ Junior Resident, Department of Community and Family Medicine, All India Institute of Medical Sciences, Raipur, Chhattisgarh; ${ }^{2}$ Additional Professor, Department of Community and Family Medicine, All India Institute of Medical Sciences, Raipur, Chhattisgarh; 3Junior Resident, Department of Community and Family Medicine, All India Institute of Medical Sciences, Raipur, Chhattisgarh

\section{Corresponding Author}

Dr Mohan Kumar, Post Graduate Junior Resident, Department of Community and Family Medicine, All India Institute of Medical Sciences, Raipur, Chhattisgarh-492099

E Mail ID: kumar.mohan324@gmail.com

\section{Citation}

Priya K, Padhy GK, Kumar M. Care of caregivers - who is responsible? Indian J Comm Health. 2021;33(2):400403. https://doi.org/10.47203/IJCH.2021.v33i02.033

Source of Funding: Nil Conflict of Interest: None declared

\section{Article Cycle}

Received: 27/04/2021; Revision: 25/05/2021; Accepted: 05/06/2021; Published: 30/06/2021 This work is licensed under a Creative Commons Attribution 4.0 International License.

\section{Abstract}

Demographic and epidemiologic transition coupled with increasing life expectancy has resulted in high old age dependency ratios and rising burden of comorbidities; especially non communicable diseases. This demands large pool of caregivers to support the dependents; physically, psychologically and financially. But the problems faced by caregivers - stress, anxiety, monetary, physical exhaustion and sickness, lack of time for personal care and health resulting in caregiver burden - is often neglected. This article summarizes the importance and/or role of caregivers, theirs problems and recommendations to identify, manage and prevent caregiver burden. The involvement of various stakeholders namely medical and para-medical colleges through training and medical education, hospitals, physicians, psychiatrists and/or psychologists, research organizations, governments and their policies is the need of the hour.

\section{Keywords}

Caregiver Burden; Life Expectancy; Non Communicable Diseases

\section{Introduction}

Care giving is the largest growing occupation in the nation. (1) A person who helps with the physical and psychological needs of another person is termed as caregiver.(2) As life expectancy has been gradually increasing over the years, so does the co-morbid conditions associated with it; the harms of benefits. Since there is an epidemiological transition from communicable to Non-Communicable Diseases (NCD), (3) people who need care and support are on rise.

Such patients are taken care by two types of service providers; Formal and Informal. Formal caregivers are those who are specially trained in care giving and are paid for their job. They can be volunteers for charity purpose or can make this their profession.(4) Formal caregivers are usually employed to provide service for a newborn (ex. Nanny), to sick patients and for elderly care. The care provided by the family members, which is unpaid, is the informal; largest sector of care giving.

No economy can replace informal caregivers with formal paid ones. This is not only due to rising old age dependency ratio and burden of NCDs, but also due to the cost of hospitalization and institutional care. Hence the need for home care is on rise. Also the role played by the care giver is more demanding; physically, psychologically and financially. Generally, women play this role more than men. In houses where both the husband and women work, it 
When care giving becomes for too long or if it is the occupation of the person, then the entire nature and mental status of such a person is altered. Their outlook becomes different. According to caregiver identity theory, care giving is a dynamic process, where changes keeps occurring in the care activities, in the relation between the giver and the recipient and finally the identity of the caregiver itself.(5)

Need for caregivers: A dependent person seeks care both in good health and sickness. In good health, certain elderly people need someone to take care of their basic needs due to their age induced changes (diminished vision due to conditions like presbyopia, age induced hearing loss). The other category is when people are sick with acute or chronic disease conditions; accident/trauma (ex. falls) related orthopedic injury, stroke, dementia, cancer.

Changing trends in care giving: Initially when India has treated family as a social institution, coresidence was the method of taking care of elderly and the sick. In India, elderly constitutes around 8.5\% of the total population. According to NSSO (National Sample Survey Organization) 60th round around $5.2 \%$ of older adults live alone. With demographic transition, families are moving towards nuclear type resulting in a gradual shift from informal to formal caregivers.(6) Also it has been shown that majority of the elderly were receiving care from formal or informal sector only when they were living with spouse and family members.

Phases in care giving: When care giving is subdivided based on the demands and needs of the patient and/or dependent, the entire process falls under the following five categories,

1. Awareness - the patient realizes he has some problem with routine work and the family member/s notices the need of the patient

2. Unfolding responsibility - for the caregiver it may be a new experience, they may learn new roles, the recipient may face some discomfort, discrimination, they might feel some loss of control or power

3. Increasing care demands - mainly for elderly or chronic disease patients with worsening prognosis. The care giving task may expand to self-care, performing medical procedures

4. End of life - care giving becomes more urgent, intensive and demanding.(7) Caregivers tend to

experience highest level of stress and burden during this phase.(8)

\section{Bereavement}

This when plotted, we can see a linear graph in case of care for a dementia patient. It can be a reverse linear for a stroke patient and highly fluctuant and rapid for a cancer patient.

Problems faced by caregivers: The problems faced by the caregivers whether they belong to the same family or paid care providers are often neglected. They can be psychological issues(9), financial(10), physical exhaustion and sickness(11), lack of time for personal care and health(12) and are summarized in (Figure 1).(13)

Caregiver burden is defined as "a multidimensional response to physical, psychological, emotional, social and financial stressors associated with the care giving experience" (14) It was found that around 70\% of working caregivers had work related difficulties due to two jobs. According to the Family Caregiver Alliance, to meet the requirements of the dependents, $69 \%$ of working caregivers had to rearrange their schedule or take an unpaid leave. $39 \%$ had to leave their jobs to provide care for their family members in need. (15) Due to negligence in own care, $40.7 \%$ of caregivers reported two or more chronic diseases themselves. $36.7 \%$ reported insufficient sleep, $14.5 \%$ and $17.6 \%$ of them were found to have mentally and physically unhealthy days in a month respectively as per Centre for Disease Control.(13) The American Cancer Society National Quality of Life Survey for Caregivers on its five year follow up study on the caregivers of cancer patients, found that those who were providing care for five years were having poorest quality of life and had the largest increase in depressive symptoms.(16) Women were found to have more psychological distress as compared to male caregivers. $(17,18)$

\section{Conclusion}

Since care giving is evolving as an important part of health care sector, it is important for the medical professionals and the government to look into the needs of the caregivers. Being a caregiver should be considered as a job in itself, and all its related issues and burden should be considered as occupational diseases / hazards. A multisectoral involvement is needed to provide a wholesome approach in designing a healthy working environment for the care providers. 


\section{Recommendation}

The recommendations grouped based on stakeholders involved are given in (Table 1).

\section{References}

1. Murthy Rs. Caregiving and caregivers: Challenges and opportunities in India. Indian Journal of Social Psychiatry. 2016 Jan $1 ; 32: 10$.

2. Hileman JW, Lackey NR, Hassanein RS. Identifying the needs of home caregivers of patients with cancer. Oncol Nurs Forum. 1992 Jun;19(5):771-7.

3. WHO EMRO. The epidemiological transition. EMHJ 1996; 2(1) Available from: http://www.emro.who.int/emhj-volume-21996/volume-2-issue-1/article2.html. (Accessed on 27/11/2020)

4. The Stano Law Firm. Informal vs. Formal Caregivers. Available from: https://stanolaw.com/informal-vs-formal-caregivers/ (Accessed on 27/06/2021)

5. Montgomery R. Caregiver Identity Theory Overview. (Accessed on 27/06/2021)

6. Ugargol AP, Hutter I, James KS, Bailey A. Care Needs and Caregivers: Associations and Effects of Living Arrangements on Caregiving to Older Adults in India. Ageing Int. 2016 Jun 1;41(2):193-213.

7. Gibbons SW, Ross A, Bevans M. Liminality as a conceptual frame for understanding the family caregiving rite of passage: an integrative review. Res Nurs Health. 2014 Oct;37(5):423-36.

8. Emanuel EJ, Fairclough DL, Slutsman J, Emanuel LL. Understanding economic and other burdens of terminal illness: the experience of patients and their caregivers. Ann Intern Med. 2000 Mar 21;132(6):451-9.
[Care of caregivers...] | Priya K et al

9. Deshpande. Insights into psychosocial problems of primary caretakers of patients with schizophrenia in India. 2018; $2 ;(2) ; 130$ 134

10. Mishra AK, Mishra N, Gajjar K. Financial burden of stroke on family and caregiver in India: a literature review. International Journal of Research in Medical Sciences. 2016 Dec 18;4(9):3675-8.

11. Demirbas H, Kizil ETO. Burnout and Related Factors in Caregivers of outpatients with Schizophrenia. Insights on the Depression and Anxiety. 2017 Jan 9;1(1):001-11.

12. Dionne-Odom JN, Demark-Wahnefried W, Taylor RA, Rocque GB, Azuero A, Acemgil A, et al. The Self-Care Practices of Family Caregivers of Persons with Poor Prognosis Cancer: Differences by Varying Levels of Caregiver Well-being and Preparedness. Support Care Cancer. 2017 Aug;25(8):2437-44.

13. Caregiving for Family and Friends - A Public Health Issue. Available from: https://www.cdc.gov/aging/caregiving/caregiver-brief.html . (Accessed on 27/06/2021)

14. Buhse M. Assessment of caregiver burden in families of persons with multiple sclerosis. J Neurosci Nurs. 2008 Feb;40(1):25-31.

15. Caregiver Statistics: Work and Caregiving. Family Caregiver Alliance. Available from: https://www.caregiver.org/caregiverstatistics-work-and-caregiving. (Accessed on 27/06/2021)

16. Kim Y, Shaffer KM, Carver CS, Cannady RS. Prevalence and predictors of depressive symptoms among cancer caregivers 5 years after the relative's cancer diagnosis. J Consult Clin Psychol. 2014 Feb;82(1):1-8.

17. Pinquart $M$, Sörenson $S$. Gender differences in caregiver stressors, social resources and health: Updated meta-analysis. The Journals of Gerontology Series B: Psychological Sciences and Social Sciences. 2006;61(1):P33-P45.

18. Yee JL, Schulz R. Gender Differences in Psychiatric Morbidity Among Family Caregivers. The Gerontologist. 2000 Apr 1;40(2):147-64.

\section{Tables}

\section{TABLE 1 RECOMMENDATIONS}

\begin{tabular}{|c|c|}
\hline $\begin{array}{l}\text { Role of medical and } \\
\text { para medical } \\
\text { colleges }\end{array}$ & $\begin{array}{l}\text { - Routine workshops, training of doctors and nurses to provide empathic care to the } \\
\text { caretakers has to be implemented } \\
\text { Care coordination and advance care planning services available to patients should be made } \\
\text { available to caretakers also }\end{array}$ \\
\hline $\begin{array}{l}\text { Role of medical } \\
\text { education }\end{array}$ & $\begin{array}{l}\text { - Empathetic counseling has to be a part of the Undergraduate medical and paramedical } \\
\text { curriculum }\end{array}$ \\
\hline $\begin{array}{l}\text { Role of treating } \\
\text { hospitals }\end{array}$ & $\begin{array}{l}\text { - The art of counseling and providing psychological support has to be part of the } \\
\text { comprehensive care at the primary health centers (PHC) as the routine follow up of patients } \\
\text { suffering from stroke, cardiovascular disease, hypertension, diabetes, cancer, dementia, } \\
\text { psychological disorders occur at the level of PHCs } \\
\text { Placing 'Personal experiences' sticky notes on display boards of the hospitals. Here the care } \\
\text { takers can pen down their feelings and emotions which they had gone through during the } \\
\text { course of taking care of the loved ones. This helps the other caretakers not feeling lonely as } \\
\text { someone had gone through all the same }\end{array}$ \\
\hline $\begin{array}{l}\text { Role of treating } \\
\text { physicians }\end{array}$ & $\begin{array}{l}\text { - When a physician treats such chronic diseases, he/she should make sure that the mental } \\
\text { health of the caretakers is also considered. } \\
\text { - There has to be routine mental health assessment and examination of such people who } \\
\text { have played the role of being chronic caretakers } \\
\text { - The care givers should be referred to Psychiatrist and psychologist on a routine basis by the } \\
\text { treating physician for their evaluation }\end{array}$ \\
\hline $\begin{array}{l}\text { Role of psychiatrists } \\
\text { / psychologist }\end{array}$ & $\begin{array}{l}\text { - Special clinics for care takers to be held once a month -once a quarter. } \\
\text { - They would enroll all the referred relatives/ care givers of chronic patients } \\
\text { - Care giver intervention module should be available in all the hospitals and made } \\
\text { appropriate use of }\end{array}$ \\
\hline Role of employers & - Regular breaks, vacations for the formal caregivers. \\
\hline
\end{tabular}


- Incentives, motivation and appreciation for all the good and efficient work done by them.

- Necessary arrangements for the caregivers to keep in touch with their families and friends.

- To make sure that education of the caregivers is not hampered

- To protect the caregivers from physical and sexual abuse

Role of government

- Separate department should be initiated to create job opportunities to employ care givers and those who need can contact government. This can create more employment opportunities.

- A wide publicity of the tollfree number should be made available

- Provision of such service in both rural and urban areas

- Streamline the salary of the caregivers

- A national policy on the role of caregivers, their health and risks should be drafted based on evidence.

- Family care leave should be made available for both public and private sector employees for a total of 60 days per parent in the entire service.

Role of insurance - Risk pooling for the care givers to prevent them from financial hardships.

schemes

- The existing insurance schemes, should include a separate provision for insurance claim by the caretakers as a part of the new scheme

Role of caregivers - Forming support groups for the caretakers by themselves

- Special breaks to rejuvenate the health of the care takers has to be ensured by other family members / employers

Research

- More research has to be undertaken in the field of health; support system available to care givers

- Surveys at national level on the percentage of care givers in India, their mental, physical, social health has to be undertaken at least once in 5 years

\section{Figures}

\section{FIGURE 1 PROBLEMS FACED BY CAREGIVERS}

\section{Emotional/ psychological issues}

Due to care for prolonged periods and handling the mood vagaries of the patients (terminally ill and mental health disorders patients.)

\section{Physical exhaustion}

The extent of laborious task exerted by the care givers over a period of time gives rise to physical exhaustion.

\section{Financial issues}

Taking care of patients of stroke, dementia, mentally retarded children can impose a lot of financial strain to the family

\section{Lack of self-care}

Since most of the time and life are spent in caring for the dependent ones, there is little time for self-care and personal improvement of the care takers. 